\title{
12-month effects of incretins versus SGLT2- Inhibitors on cognitive performance and metabolic profile. A randomized clinical trial in the elderly with Type-2 diabetes mellitus
}

This article was published in the following Dove Press journal:

Clinical Pharmacology:Advances and Applications

\begin{abstract}
Simone Perna'
Manuela Mainardi

Paolo Astrone ${ }^{2}$

Carlotta Gozzer ${ }^{3}$

Anna Biaval

Ruben Bacchio ${ }^{3}$

Daniele Spadaccini ${ }^{3}$

Sebastiano Bruno Solerte ${ }^{2}$

Mariangela Rondanelli ${ }^{4}$

'Department of Biology, College of Science, University of Bahrain, Sakhir Campus, Kingdom of Bahrain; ${ }^{2}$ University of Pavia, Department of Internal Medicine, Section of Geriatrics and Gerontology, Azienda di Servizi alla Persona "Istituto Santa Margherita”, Pavia, Italy; ' $U$ niversity of Pavia, Department of Public Health, Experimental and Forensic Medicine, Section of Human Nutrition, Endocrinology and Nutrition Unit, Azienda di Servizi alla Persona "Istituto SantaMargherita", Pavia, Italy; ${ }^{4}$ IRCCS Mondino Foundation, Pavia, Department of Public Health, Experimental and Forensic Medicine, Unit of Human and Clinical Nutrition, University of Pavia, Italy
\end{abstract}

Correspondence: Simone Perna Department of Biology, College of Science, University of Bahrain, Sakhir Campus PO Box 32038, Kingdom of Bahrain

Tel +390382381706

Email simoneperna@hotmail.it

\begin{abstract}
Aim: The aim of the present study is to examine the effects on cognitive performance, anthropometric measures, and metabolic markers in 2 different treatments: Incretins vs sodium-glucose co-transporter-2 inhibitors (SGLT2-I).

Materials and methods: A randomized controlled clinical trial was carried out on 39 elderly subjects (23 men and 16 women) with type 2 diabetes mellitus, with a mean age of $77.21 \pm 8.07$ years. Body mass index (BMI) of $29.92 \pm 4.31 \mathrm{~kg} / \mathrm{m}^{2}$ and a cognitive status measured by a Mini Mental State Examination (scores $>27$ points). The subjects were on a 3-month treatment with a maximal dose of metformin as a stable regime, with the addition of incretins (liraglutide at doses of up to $1.8 \mathrm{mg} / \mathrm{d}$; vildagliptin at $100 \mathrm{mg} / \mathrm{d}$; sitagliptin $100 \mathrm{mg} / \mathrm{d}$; and linagliptin $5 \mathrm{mg} / \mathrm{d}$ ), or SGLT2-I (canagliflozin $300 \mathrm{mg} / \mathrm{d}$; empagliflozin $25 \mathrm{mg} / \mathrm{d}$; and dapagliflozin $10 \mathrm{mg} / \mathrm{d}$ ). Glucose control was monitored by fasting glucose and glycosylated hemoglobin. Cognitive performance (by way of Verbal Fluency Test, Attentive Matrices Test, and Babcock Story Recall Test), anthropometric measures, and plasma lipids were also evaluated.

Results: Cognitive status did not change significantly during the 12 months of treatment in either group: Verbal Fluency Test: (SGLT2-I: $P=1.00$, incretins: $P=0.598$ ); Babcock Story Recall Test (SGLT2-I: $P=0.391$; incretins: $P=0.351$ ); and Attentive Matrices Test (SGLT2-I: $P=0.679$, incretins: $P=0.901)$. SGLT2-I also resulted in a reduction in weight $(-1.95 \mathrm{~kg} ; P<0.05)$, in BMI $(-0.69$ $\left.\mathrm{kg} / \mathrm{m}^{2} ; P<0.05\right)$ and an increase in high-density lipoprotein cholesterol $(+5.73 \mathrm{mg} / \mathrm{dl} ; P<0.01)$. Conclusion: Preliminary data show that patients treated with incretins and SGLT2-I have not suffered a reduction in cognitive performance during the 1 year of treatment. Metabolic outcome seemed to benefit, in particular, in patients who were treated with SGLT2-I.
\end{abstract}

Keywords: SGLT-2 inhibitors, incretins, cognitive performance, cognitive impairment, metabolic outcome

\section{Introduction}

Type 2 diabetes mellitus (T2DM) is a common and complex metabolic disease that can have devastating effects on multiple organs in the body. The deleterious effects of diabetes on the cardiovascular, renal, retinal, and peripheral nervous systems are widely acknowledged. ${ }^{1,2}$

Less attention has been given to the effect of diabetes on cognitive function. Patients with diabetes mellitus have been found to have cognitive deficits that can be attributed to their disease, so cognitive decline and dementia are now recognized and investigated as diabetes-related complications. ${ }^{3-6}$ 
The relation between diabetes and cognitive dysfunction in patients with diabetes has not been completely elucidated. Individuals with diabetes are $\sim 1.5$ times more likely to experience cognitive decline and frank dementia than individuals without diabetes. $^{7}$

Many studies demonstrated that diabetic elders with normal cognition have poorer cognitive outcomes than nondiabetic elders and that diabetic elders receiving diabetes treatment demonstrate better outcomes than those not receiving treatment. ${ }^{8}$

According to Action to Control Cardiovascular Risk in Diabetes trial, higher HbAlc levels are associated with lower cognitive function in individuals with diabetes and an improved glycemic control in the elderly patient with diabetes may have beneficial effects on cognitive functions..$^{9,10}$ Many hypotheses with supporting evidence exist, including potential causative roles for hyperglycemia, vascular disease, hypoglycemia, insulin resistance, inflammatory cytokines, and oxidative stress. The cause of cognitive dysfunction in patients with diabetes is likely a combination of these factors, depending on the patient's type of diabetes, comorbidities, age, and type of therapy. ${ }^{11-13}$

Several diabetes therapies are currently available; among them, 2 new treatments have been recently developed for T2DM: Incretins and sodium-glucose co-transporter-2 inhibitors (SGLT2-I).

Incretin mimetics (Glucagone-like peptide-1 [GLP-1] analogs] and enhancers (dipeptidyl peptidase-4 [DPP-4] inhibitors) are 2 classes of therapeutic agents for the treatment of T2DM.

Incretins are a group of metabolic hormones released during meals from gut endocrine cells. They stimulate insulin secretion in a glucose-dependent manner, delay gastric emptying, and suppress appetite. Incretins hormones are rapidly inactivated by the enzyme DPP-4 produced in the intestines. The effect of incretins is severely reduced in patients with T2DM, therefore, 2 pharmacological approaches have been taken to enhance the incretin action. One approach is to administer GLP-1 analogs that are not broken down by DPP-4. The other one is to inhibit DPP-4 activity. ${ }^{14-16}$

Incretin-based therapy appears to be associated with a reduction in $\mathrm{HbA} 1 \mathrm{c}$, especially with long-acting GLP-1 receptor agonists, reduction in blood pressure, and improvement in lipid profile. Furthermore, incretins have shown a very low risk of hypoglycemia. The injectable GLP-1 receptor agonists also reduce body weight whereas the DPP-4 inhibi- tors are weight neutral. Weight reduction mainly reflects loss of abdominal visceral fat. ${ }^{17-20}$

Diabetes is a risk factor for worsening cognitive health. Studies that have investigated the effects of incretins on cognition have proved to be beneficial.

DPP-4 inhibitors administration in older patients with T2DM protects against worsening cognitive function. ${ }^{21,22}$

Moreover, in animal studies, GLP-1 analogs have been shown to prevent cognitive impairment in T2DM models. ${ }^{23-25}$

Beyond incretins, SGLT2-I represent a newly developed class of oral anti-diabetic drugs with a unique mechanism of action. ${ }^{26}$

SGLT2 is a glucose transporter located in the proximal tubule in the kidneys. It is responsible for $90 \%$ of glucose reabsorption. Inhibition of SGLT2 decreases blood glucose due to the increase in renal glucose excretion. ${ }^{27,28}$

The efficacy and safety of SGLT2-I have been investigated in several trials showing improved glucose control with a decrease in $\mathrm{HbA} 1 \mathrm{c}$, a reduction in body weight and a reduction in systolic and diastolic blood pressure. Moreover, all SGLT2-I modestly increase high-density lipoprotein (HDL)-cholesterol levels and are effective in improving cardiometabolic markers. ${ }^{29-32}$

There are few studies in vivo that have evaluated the efficacy of SGLT2-I on cognitive status.

An experimental study was performed to investigate the effects of long-term empagliflozin treatment on cognitive dysfunction in mice. Empagliflozin significantly prevented the progression of cognitive impairment in diabetic mice. The improvement of cognitive function seems to be attributed to the attenuation of oxidative stress. ${ }^{33}$

Given this background, the aim of the present study is to examine the effects of 2 different treatments: Incretins vs SGLT2-I on cognitive impairment and metabolic outcomes, such as glycemic and lipid profile, and anthropometric outcomes.

\section{Materials and methods Study participants}

The study was performed following approval by the Ethics Committee of the Department of Internal Medicine and Medical Therapy of the University of Pavia (Reg. no. IT01001). Subjects gave their written informed consent to the study.

We evaluated elderly ( $>65$ years of age) men and women with T2DM admitted to the outpatient setting of Azienda Servizi alla Persona, Istituto Santa Margherita Hospital in Pavia, between January 2016 and March 2017. 
A detailed medical history of T2DM was obtained and included diabetes duration, current treatment for diabetes and any complications, family history of diabetes, comorbid diseases of the patient, and their treatment.

The inclusion criteria were as follows: 1 ) diabetic patients with healthy cognition, 2) absence of acute or chronic neurological disease, mental disorders, sensorial impairment, and alcoholism, and 3) age $>65$ years.

The exclusion criteria were as follows: 1) treatment with steroids or nonsteroidal anti-inflammatory drugs. 2) dementia or mild cognitive Impairment according to Diagnostic and Statistical Manual of Mental Disorders, Fifth Edition criteria. $^{34}$

In particular, we performed a mini mental state examination (MMSE) with a view to excluding subjects scoring $<27$ points. ${ }^{35,36} \mathrm{We}$ excluded subjects with mild cognitive impairment because they should be evaluated by geriatric specialists and should take specific treatments (eg, citicoline), which can ameliorate cognitive performance.

\section{Anthropometric measures}

Body weight was measured to the nearest $0.1 \mathrm{~kg}$ by using a precision scale with the subjects wearing light clothing and without shoes, using a standardized technique. Body mass index (BMI) and waist circumference were also calculated. ${ }^{37}$

\section{Biochemical analyses}

All the blood draws were obtained in the fasted state at baseline and after 12 months. The blood samples were taken and immediately cooled and centrifuged at $4^{\circ} \mathrm{C}$, then stored at $-80^{\circ} \mathrm{C}$ until analysis.

$\mathrm{HbA1c}$ was analyzed using a high-performance liquid chromatography, ion-exchange chromatography assay (HLC723G7, TOSOH, Japan). Serum glucose, creatinine, and lipid profiles were determined by using the Hitachi 7070 automatic biochemical analyzer (Hitachi Ltd, Tokyo, Japan).

\section{Cognitive performance}

The neuropsychological assessment was performed with a previously established test battery consisting of 3 verbal and nonverbal tasks addressing various cognitive domains. The neuropsychological tests were performed in an outpatient setting in the morning and after breakfast to exclude hypoglycemia. The tests were administered in a fixed order, and the entire battery took about 25 minutes to complete. Recertification of test performance was repeated 12 months later.
The Attentive Matrices Test is a valid tool for measuring visual motor speed, selective and sustained attention. ${ }^{38,39}$ The Verbal Fluency Test (sometimes called category fluency or semantic fluency) requires subjects to generate as many words as possible in 2 minutes for a given category (colors, animals, fruits, and cities). ${ }^{40}$ Finally, the Babcock Story Recall Test was a semantic verbal long-term memory measure during which a brief story was read to participants who were asked to provide immediate and delayed recall. ${ }^{41}$

\section{Randomization}

Randomization was performed after the baseline assessment; in addition, any variable that identified personal information was not included in the randomization process.

Computer-generated random numbers were assigned to 50 participants who were then sorted and divided equally into 2 groups. The groups were randomly assigned to 1 of the 2 intervention groups: Incretins (25 participants) and SGLT2-I (25 participants). All participants agreed with the group allocations mailed to them.

\section{Intervention and duration}

The trial was randomized using a 2 parallel group design. The participants were randomly assigned to 1 of the following 2 daily treatments for 52 weeks:

1. Incretins (liraglutide at doses up to $1.8 \mathrm{mg}$ /day; vildagliptin at $100 \mathrm{mg}$ /day; sitagliptin $100 \mathrm{mg}$ /day; and linagliptin $5 \mathrm{mg} /$ day);

2. SGLT2-I (canagliflozin $300 \mathrm{mg} /$ day; empagliflozin 25 $\mathrm{mg}$ /day; and dapagliflozin $10 \mathrm{mg} /$ day).

\section{Sample size}

Univariate one-factor repeated-measures ANOVA was used to examine significant differences in means at baseline and after 12 months. Intervention $(\alpha=0.05$ and power $=0.80)$ with an effective size of 0.15 required a sample size of at least 40 participants in each group.

\section{Statistical analysis}

All analyses were performed using Statistical Package for the Social Sciences, version 22.0 (SPSS Inc., Chicago, IL, USA). Descriptive statistics representing raw data for each of the 3 categories and the full sample were provided, including means, SDs, and frequencies, where appropriate.

Following verification of the normal distribution of the continuous variables, the baseline data were analyzed and 
statistically compared between groups using the one-way ANOVA. Variances were considered to be statistically significant for $P$-value $<0.05$.

Data were analyzed with SPSS general linear modeling repeated measures to test the hypothesized effects of the intervention over time. In addition, we analyzed the groups using linear regression models adjusted for gender and age.

\section{Results}

Eleven subjects had MMSE <27; so, they were excluded because they have take specific treatments (eg, citicoline) that can ameliorate cognitive performance. Only 39 subjects completed the study.

Table 1 shows baseline characteristics of 39 subjects (23 male, 16 female) at admission. The sample had a mean age of $77.21 \pm 8.07$ years, a mean BMI of $29.92 \pm 4.31 \mathrm{~kg} / \mathrm{m}^{2}$ and was overweight or obese.

While the mean values of the lipid profile were within the normal range, the mean triglycerides was $122.11 \pm 44.08 \mathrm{mg}$ / $\mathrm{dL}$ and the mean total cholesterol was $150.42 \pm 21.65 \mathrm{mg} / \mathrm{dL}$.
Furthermore, the mean HDL-cholesterol was 43.79 \pm 11.30 $\mathrm{mg} / \mathrm{dL}$ and the mean low-density lipoprotein (LDL)-cholesterol was $83.26 \pm 22.03 \mathrm{mg} / \mathrm{dL}$.

The average value of $\mathrm{HbA1c}$ was $7.16 \% \pm 1.18 \%$ and stated that patients were classified as T2DM.

As regards differences between groups at baseline, differences in total and LDL-cholesterol were highlighted. No other statistically significant differences were assessed. Table 2 reports mean changes from baseline values, through intra- and between-groups analysis. Pre-post means differences in lipid, glycemic, and anthropometric profiles are also reported in Figures 1-3. A flow diagram of the study is reported in Figure 4.

In the intra-group analysis, we found statistically significant differences (pre-post) in the SGLT2-I group in terms of body weight $(-1.95 \mathrm{~kg} ; P<0.05)$, BMI $\left(-0.69 \mathrm{~kg} / \mathrm{m}^{2} ; P<0.05\right)$, and higher HDL cholesterol $(+5.73 \mathrm{mg} / \mathrm{dL} ; P<0.01)$. No other statistically significant differences were found.

In the intra-group analysis of the incretins group, we did not find any significant differences (pre-post).

Table I Baseline characteristics of the sample

\begin{tabular}{|c|c|c|c|c|}
\hline \multirow[t]{2}{*}{ Variables } & \multirow{2}{*}{$\begin{array}{l}\text { Total (39; } \\
\text { women: 16; } \\
\text { men: } 23) \\
\text { mean } \pm \text { SD }\end{array}$} & \multirow{2}{*}{$\begin{array}{l}\text { Incretins } \\
\text { group (18; } \\
\text { women: 8; } \\
\text { men: 10) } \\
\text { mean } \pm \text { SD } \\
\end{array}$} & \multirow{2}{*}{$\begin{array}{l}\text { SGLT2-I } \\
\text { group (2 I; } \\
\text { women: } 8 ; \\
\text { men: I3) } \\
\text { mean } \pm \text { SD }\end{array}$} & \multirow[t]{2}{*}{$\begin{array}{l}\text { Sig } P \text {-value } \\
\text { Between } \\
\text { groups at } \\
\text { baseline }\end{array}$} \\
\hline & & & & \\
\hline Age (years) & $77.21 \pm 8.07$ & $77.00 \pm 8.73$ & $77.36 \pm 7.98$ & 0.927 \\
\hline \multicolumn{5}{|l|}{ Anthropometric measures } \\
\hline Body weight (kg) & $85.50 \pm 16.15$ & $82.19 \pm 20.92$ & $87.91 \pm 12.17$ & 0.503 \\
\hline BMI $\left(\mathrm{kg} / \mathrm{m}^{2}\right)$ & $29.92 \pm 4.31$ & $29.47 \pm 6.36$ & $30.25 \pm 2.21$ & 0.749 \\
\hline Waist circumference $(\mathrm{cm})$ & $103.37 \pm 9.77$ & $98.75 \pm 10.86$ & $106.73 \pm 7, .72$ & 0.101 \\
\hline Serum creatinine $(\mathrm{mg} / \mathrm{dL})$ & $0.92 \pm 0.23$ & $0.92 \pm 0.21$ & $0.92 \pm 0.26$ & 0.994 \\
\hline \multicolumn{5}{|l|}{ Glucose control variables } \\
\hline Duration of diabetes (years) & $11.21 \pm 7.02$ & $8.38 \pm 3.81$ & $|3.27 \pm 8.3|$ & 0.103 \\
\hline Blood glucose level (mg/dL) & $129.26 \pm 30.17$ & $115.50 \pm 18.68$ & $139.27 \pm 33.66$ & 0.067 \\
\hline $\mathrm{HbAlc}(\%)$ & $7.16 \pm 1.18$ & $6.6 \pm 0.71$ & $7.56 \pm 1.31$ & 0.059 \\
\hline \multicolumn{5}{|l|}{ Lipid profile } \\
\hline Triglycerides (mg/dL) & $122.11 \pm 44.08$ & $119.75 \pm 42.80$ & $123.82 \pm 46.98$ & 0.847 \\
\hline Cholesterol (mg/dL) & $|50.42 \pm 2| .65$ & $162.50 \pm 21.29$ & $|4| .64 \pm 18.02$ & $<0.05$ \\
\hline HDL-C (mg/dL) & $43.79 \pm 11.30$ & $45.50 \pm 10.70$ & $42.55 \pm 12.07$ & 0.581 \\
\hline LDL-C (mg/dL) & $83.26 \pm 22.03$ & $95.96 \pm 23.11$ & $74.02 \pm 16.63$ & $<0.05$ \\
\hline \multicolumn{5}{|l|}{ Cognitive variables } \\
\hline Verbal fluency test (score) & $3.26 \pm 1.05$ & $3.25 \pm 1.04$ & $3.27 \pm 1.10$ & 0.964 \\
\hline Babcock Story Recall Test (score) & $2.53 \pm 0.96$ & $2.63 \pm 0.74$ & $2.45 \pm 1.13$ & 0.697 \\
\hline Babcock Story Recall Test (corrected score) & $12.19 \pm 2.13$ & $12.30 \pm 1.93$ & $12.11 \pm 2.36$ & 0.848 \\
\hline Attentive Matrices Test (score) & $3.11 \pm 1.05$ & $3.5 \pm 0.93$ & $2.82 \pm 1.08$ & 0.158 \\
\hline
\end{tabular}

Note: $P$-values in bold are stylistically significant.

Abbreviations: BMI, body mass index; HDL-C, high-density lipoprotein cholesterol; LDL-C, low-density lipoprotein cholesterol; SGLT2-I, sodium-glucose co-transporter-2 inhibitors. 
Table 2 Effects of the interventions intra, and between groups in metabolic and cognitive outcomes

\begin{tabular}{|c|c|c|c|c|c|c|c|c|c|}
\hline \multirow[t]{2}{*}{ Variables } & \multicolumn{3}{|l|}{ SGLT2-I } & \multicolumn{3}{|l|}{ Incretins } & \multicolumn{3}{|c|}{ Between groups: SGLT2-I vs incretins } \\
\hline & $\begin{array}{l}\text { Mean } \\
\text { changes } \\
\text { from } \\
\text { baseline } \\
\left(t_{1}-t_{0}\right)\end{array}$ & $P$-value & $95 \% \mathrm{Cl}$ & $\begin{array}{l}\text { Mean } \\
\text { changes } \\
\text { from } \\
\text { baseline } \\
\left(t_{1}-t_{0}\right)\end{array}$ & $P$-value & $95 \% \mathrm{Cl}$ & $\begin{array}{l}\text { Mean } \\
\text { changes } \\
\text { Between } \\
\text { groups } \\
\text { (A-B) } \\
\end{array}$ & $P$-value & $95 \% \mathrm{Cl}$ \\
\hline \multicolumn{10}{|l|}{$\begin{array}{l}\text { Anthropometric } \\
\text { measures }\end{array}$} \\
\hline Body weight (kg) & -1.95 & $<0.05$ & $\begin{array}{l}(-3.73 \\
\text { to } 0.17)\end{array}$ & 0.31 & 0.812 & $\begin{array}{l}(-2.68 \\
\text { to } 3.30)\end{array}$ & -0.07 & 0.969 & $\begin{array}{l}(-4.37 \text { to } \\
4.22)\end{array}$ \\
\hline BMI $\left(\mathrm{kg} / \mathrm{m}^{2}\right)$ & -0.69 & $<0.05$ & $\begin{array}{l}(-1.33 \\
\text { to } 0.05)\end{array}$ & 0.15 & 0.773 & $\begin{array}{l}(-1.04 \\
\text { to } 1.34)\end{array}$ & -0.07 & $<0.05$ & $\begin{array}{l}(-1.63 \text { to } \\
1.48)\end{array}$ \\
\hline $\begin{array}{l}\text { Waist } \\
\text { circumference }(\mathrm{cm})\end{array}$ & -2.36 & 0.087 & $\begin{array}{l}(-5.14 \\
\text { to } 0.4 I)\end{array}$ & -0.12 & 0.901 & $\begin{array}{l}(-2.43 \\
\text { to } 2.17)\end{array}$ & -0.46 & 0.883 & $\begin{array}{l}(-7.54 \text { to } \\
6.62)\end{array}$ \\
\hline $\begin{array}{l}\text { Serum creatinine } \\
(\mathrm{mg} / \mathrm{dL})\end{array}$ & 0.02 & 0.673 & $\begin{array}{l}(-0.07 \\
\text { to } 0.1 \mathrm{I})\end{array}$ & 0.05 & 0.241 & $\begin{array}{l}(-0.04 \\
\text { to } 0.14)\end{array}$ & -0.248 & 0.050 & $\begin{array}{l}(-0.50 \text { to } \\
0.00)\end{array}$ \\
\hline \multicolumn{10}{|l|}{ Glycemic profile } \\
\hline $\begin{array}{l}\text { Blood glucose } \\
\text { level (mg/dL) }\end{array}$ & -0.91 & 0.955 & $\begin{array}{l}(-36.03 \\
\text { to } \\
34.21)\end{array}$ & 5.75 & 0.397 & $\begin{array}{l}(-9.31 \\
\text { to } \\
20.8 I)\end{array}$ & -59.78 & 0.132 & $\begin{array}{l}(-142.63 \text { to } \\
23.06)\end{array}$ \\
\hline HbAlc (\%) & -0.17 & 0.229 & $\begin{array}{l}(-0.47 \\
\text { to } 0.13)\end{array}$ & 0.00 & 1.000 & $\begin{array}{l}(-0.35 \\
\text { to } 0.35)\end{array}$ & -0.29 & 0.304 & $\begin{array}{l}(-0.89 \text { to } \\
0.32)\end{array}$ \\
\hline \multicolumn{10}{|l|}{ Lipid profile } \\
\hline $\begin{array}{l}\text { Triglycerides }^{\mathrm{a}}(\mathrm{mg} / \\
\mathrm{dL})\end{array}$ & -11.27 & 0.204 & $\begin{array}{l}(-29.76 \\
\text { to } 7.21)\end{array}$ & -10.00 & 0.501 & $\begin{array}{l}(-43.30 \\
\text { to } \\
23.30)\end{array}$ & -18.43 & 0.230 & $\begin{array}{l}(-52.99 \text { to } \\
15.10)\end{array}$ \\
\hline $\begin{array}{l}\text { Cholesterol (mg/ } \\
\mathrm{dL})\end{array}$ & 2.82 & 0.410 & $\begin{array}{l}(-4.49 \\
\text { to } \\
10.13)\end{array}$ & 0.62 & 0.943 & $\begin{array}{l}(-19.15 \\
\text { to } \\
20.40)\end{array}$ & 5.84 & 0.751 & $\begin{array}{l}(-36.09 \text { to } \\
47.78)\end{array}$ \\
\hline HDL-C(mg/dL) & 5.73 & $<0.01$ & $\begin{array}{l}(1.68 \text { to } \\
9.77)\end{array}$ & 4.25 & 0.215 & $\begin{array}{l}(-3.13 \\
\text { to } \\
11.63)\end{array}$ & 5.25 & 0.389 & $\begin{array}{l}(-8.26 \text { to } \\
18.75)\end{array}$ \\
\hline LDL-C (mg/dL) & -0.17 & 0.960 & $\begin{array}{l}(-7.67 \\
\text { to } 7.32)\end{array}$ & -4.62 & 0.434 & $\begin{array}{l}(-17.81 \\
\text { to } 8.56)\end{array}$ & 7.04 & 0.535 & $\begin{array}{l}(-18.46 \text { to } \\
32.54)\end{array}$ \\
\hline \multicolumn{10}{|l|}{ Cognitive } \\
\hline $\begin{array}{l}\text { Verbal fluency test } \\
\text { (score) }\end{array}$ & 0.00 & 1.000 & $\begin{array}{l}(-4.25 \\
\text { to } 4.25)\end{array}$ & -0.12 & 0.598 & $\begin{array}{l}(-0.66 \\
\text { to } 0.4 I)\end{array}$ & -0.65 & 0.247 & $\begin{array}{l}(-1.86 \text { to } \\
0.56)\end{array}$ \\
\hline $\begin{array}{l}\text { Babcock Story } \\
\text { Recall Test (score) }\end{array}$ & -0.27 & 0.391 & $\begin{array}{l}(-0.95 \\
\text { to } 0.40)\end{array}$ & 0.37 & 0.351 & $\begin{array}{l}(-0.5 \mathrm{I} \\
\text { to I.26) }\end{array}$ & -1.93 & 0.054 & $\begin{array}{l}(-3.91 \text { to } \\
0.04)\end{array}$ \\
\hline $\begin{array}{l}\text { Babcock Story } \\
\text { Recall Test } \\
\text { (corrected score) }\end{array}$ & -1.32 & 0.178 & $\begin{array}{l}(-3.36 \\
\text { to } 0.7 I)\end{array}$ & 0.42 & 0.674 & $\begin{array}{l}(-1.84 \\
\text { to } 2.67)\end{array}$ & -3.57 & 0.151 & $\begin{array}{l}(-8.80 \text { to } \\
1.66)\end{array}$ \\
\hline $\begin{array}{l}\text { Attentive Matrices } \\
\text { Test (score) }\end{array}$ & -0.09 & 0.676 & $\begin{array}{l}(-0.56 \\
\text { to } 0.38)\end{array}$ & -0.42 & 0.901 & $\begin{array}{l}(-4.33 \\
\text { to } 5.47)\end{array}$ & -0.34 & 0.553 & $\begin{array}{l}(-1.64 \text { to } \\
0.96)\end{array}$ \\
\hline
\end{tabular}

Notes: $P$-values in bold are stylistically significant. aMean changes intragroup and between were adjusted for sex and age.

Abbreviations: BMI, body mass index; HDL-C, high-density lipoprotein cholesterol; LDL-C, low-density lipoprotein cholesterol; SGLT2-I, sodium-glucose co-transporter-2 inhibitors.

Cognitive status did not change significantly during the 12 months of treatment in either of the groups: Verbal Fluency Test: (SGLT2-I: $P=1.00$, incretins: $P=0.598$ ), Babcock Story Recall Test (SGLT2-I: $P=0.391$; incretins: $P=0.351$ ), and Attentive Matrices Test (SGLT2-I: $P=0.679$, incretins: $P=0.901)$.
Between-groups analysis did not show any differences comparing SGLT2-I vs incretins.

\section{Discussion}

For the first time in literature, this study has compared 2 different anti-hyperglycemic agents for treatment of T2DM 

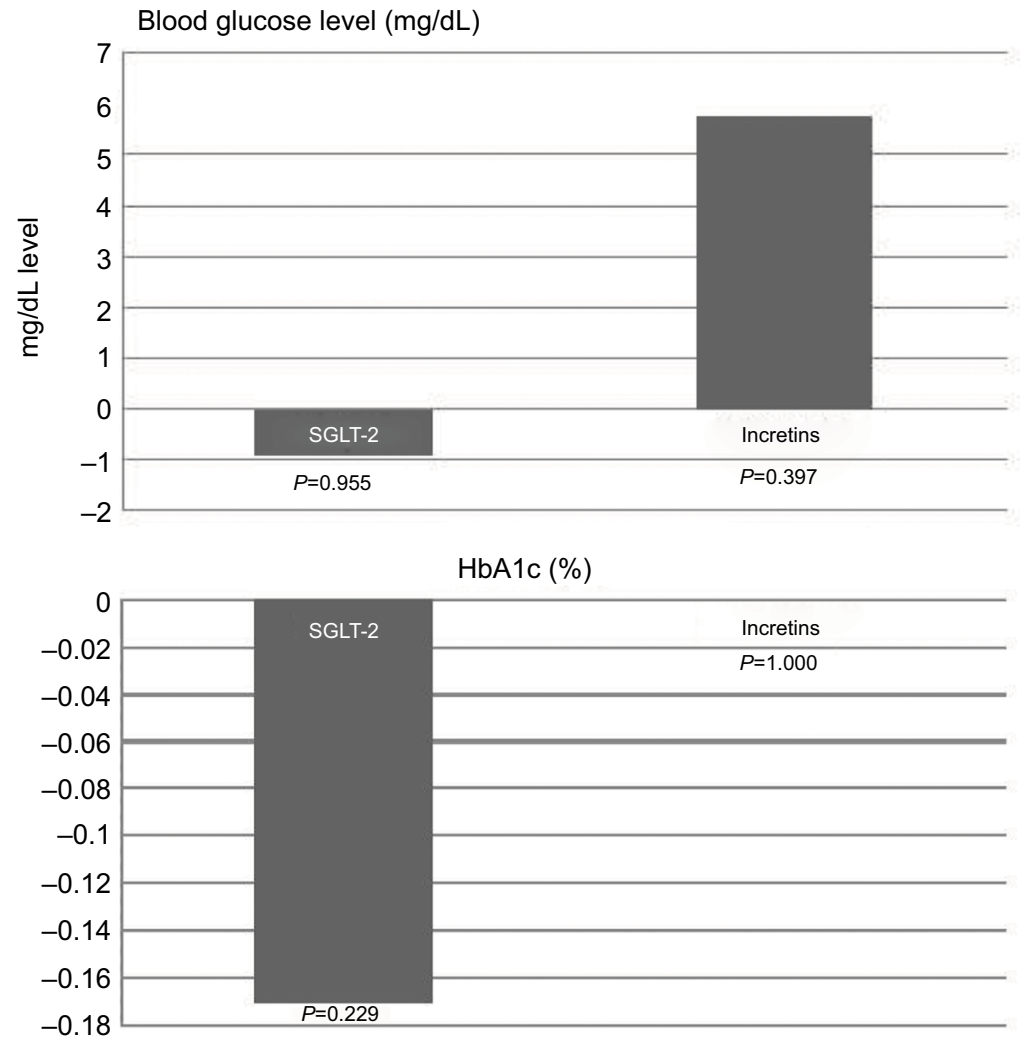

Figure I Pre-post means differences in glycemic profile.
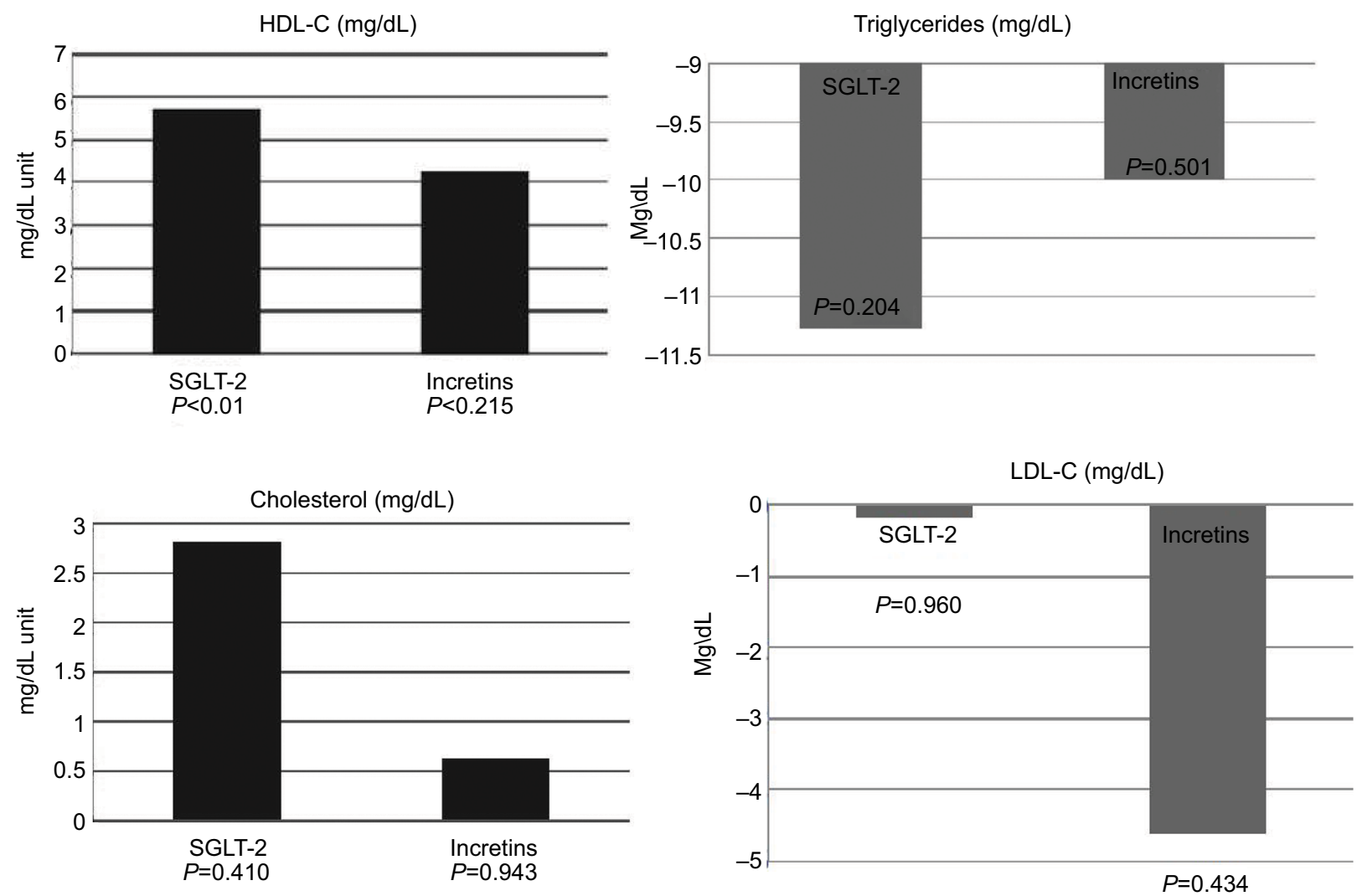

Figure 2 Pre-post means differences in lipid profile.

Abbreviations: BMI, body mass index; HDL-C, high-density lipoprotein cholesterol; LDL-C, low-density lipoprotein cholesterol; SGLT2-I, sodium-glucose co-transporter-2 inhibitors. 

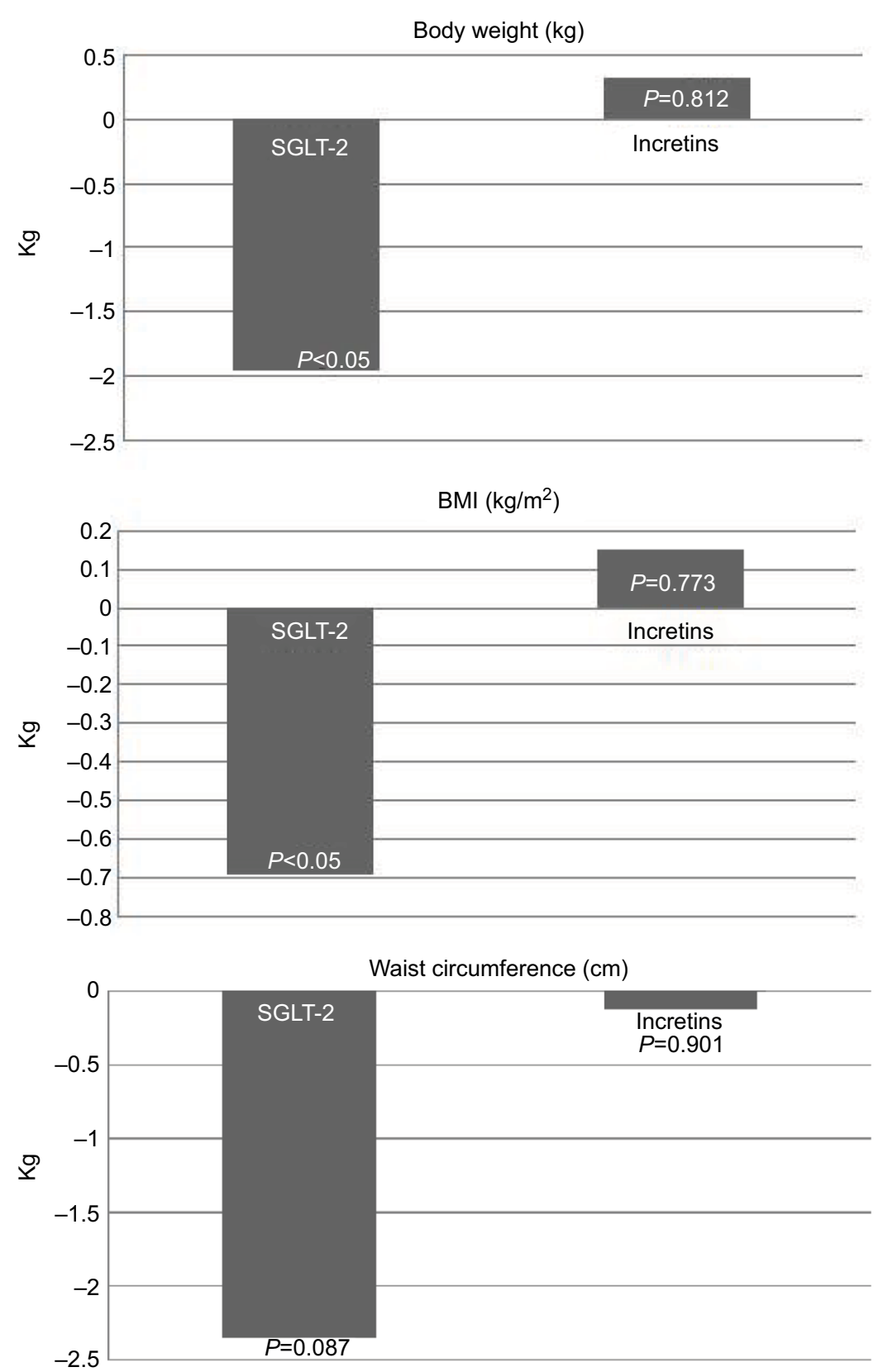

Figure 3 Pre-post intervention means differences in anthropometric measures.

Abbreviations: BMI, body mass index; SGLT2-I, sodium-glucose co-transporter-2 inhibitors.

(SGLT2-I and incretins, including DPP-4 inhibitors and GLP-1 receptor agonists). The primary outcome was to evaluate the protective effect of these 2 classes of drugs on cognitive function, under some cognitive domains in patients without cognitive impairment at baseline. We also evaluated secondary outcomes, such as anthropometric variables and metabolic profile (in particular, both lipidic and glucidic profiles). As demonstrated in many studies in murine mod- els, ${ }^{42-52}$ and in less numerous studies in populations, ${ }^{21,53-55}$ in Italian elderly patients, treatment with SGLT2-I or incretins was accompanied by stable cognitive performance after 1 year of follow-up; in fact, the scores of all administered cognitive tests did not change significantly. Therefore, we might assume that the condition of euglycemia associated with the attenuation of oxidative stress and inflammatory reaction could preserve or even improve cognitive functions. 


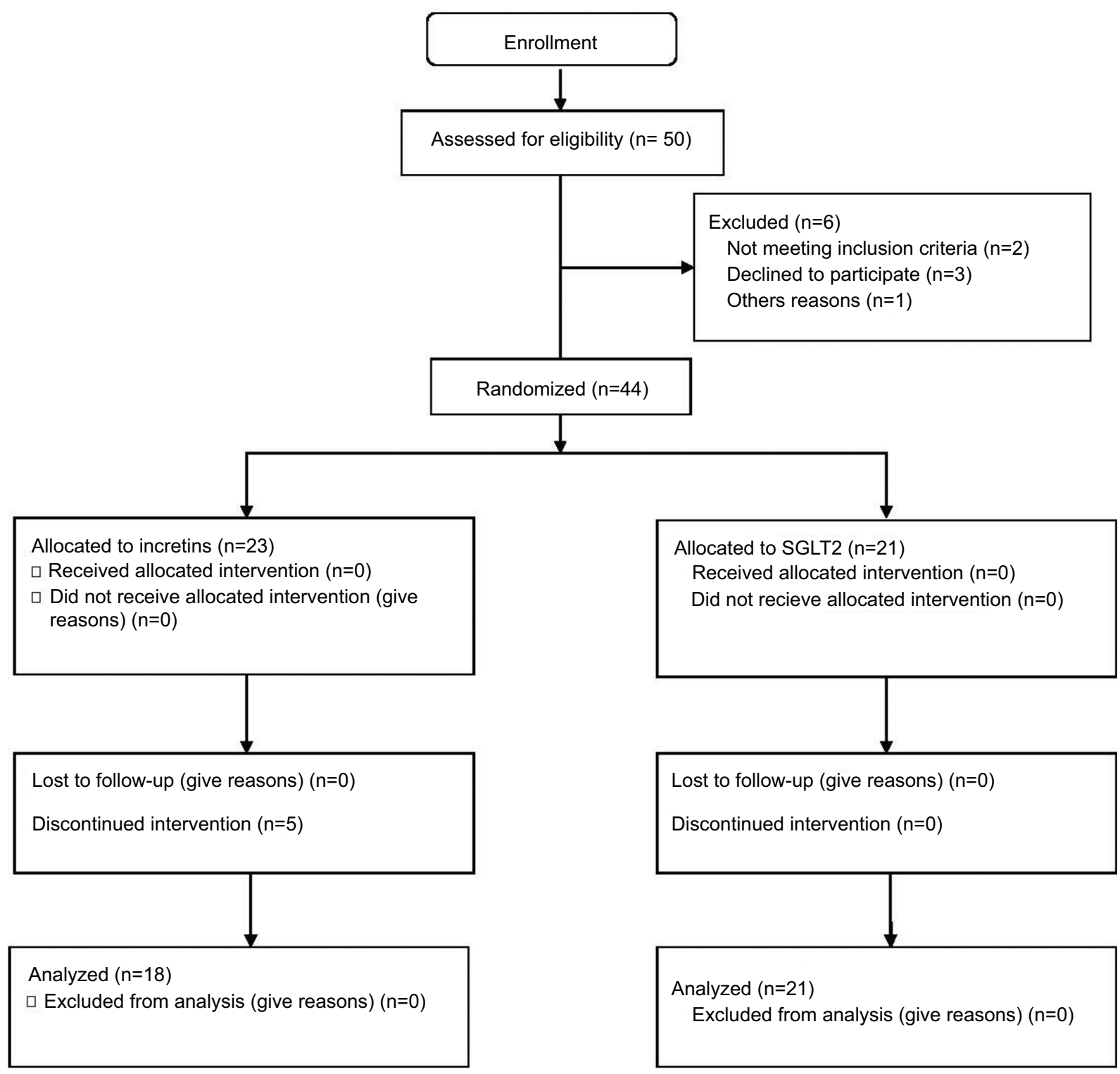

Figure 4 Flow diagram of the study.

Abbreviations: SGLT2-I, sodium-glucose co-transporter-2 inhibitors.

A limitation to our study was its duration: it lasted only 12 months. In this time period, we were not able to draw any definitive conclusion, but we can suppose that both SGLT2-I and incretins play a protective role for cognitive impairment in elderly patients with T2DM.

Another interesting finding relates to the variation of anthropometric measures and lipid profile in T2DM patients treated with SGLT2-I.

In these patients, we found a significant reduction in body weight $(-1.95 \mathrm{~kg})$ and BMI $\left(-0.69 \mathrm{~kg} / \mathrm{m}^{2}\right)$ and an almost significant decrease in waist circumference. $(-2.36 ; P$-value
0.087). Moreover, considering the lipid profile, we found a significant increase in HDL-cholesterol levels $(+5.73 \mathrm{mg} /$ $\mathrm{dL} ; P$-value $<0.01)$. One clinical trial that has investigated the efficacy of SGLT2-I compared with placebo or other glucose-lowering drugs showed similar results. ${ }^{33}$ However, the increase in HDL-cholesterol found in this study (+5.73 $\mathrm{mg} / \mathrm{dL}$ ), compared with the other trials, is a better result. Even if the effects of SGLT2-I on the overall lipid profile should be further investigated; the increase in HDL-cholesterol levels, however, may explain a potential microvascular and cardiovascular benefit of these drugs. Conversely, in this 
study, no evidence of such results was found in patients treated with incretins.

In terms of adverse events, SGLT2-I are generally well-tolerated. The most relevant undesirable effect is an increased risk of genitourinary infections as a direct effect of glycosuria. Infections of the upper urinary tract were not consistently increased by SGLT2-I in studies vs placebo, whereas all inhibitors significantly increased the risk of genital mycotic infections, especially in elderly women. ${ }^{29,56-59}$

Regarding Incretin-based therapy, the most frequently observed adverse events with GLP-1 receptor agonists were gastrointestinal disorders, particularly nausea, vomiting, and diarrhea. ${ }^{60-62}$

In rodent models, GLP-1 receptor agonists have been linked to the release of calcitonin, and the potential formation of thyroid tumors, especially medullary thyroid carcinoma. ${ }^{63}$ However, there is no evidence of a causal relationship between GLP-1RAs and thyroid tumors in humans. ${ }^{60}$

Another theoretical risk associated with incretin-based therapy is the risk of acute or chronic pancreatitis, which has been observed both for GLP-1 analogs and DPP-4 inhibitors.

A small number of cases with pancreatitis have been reported in patients treated with incretin-based drugs without, however, being able to establish if there is a causal relationship, as T2DM patients are predisposed to develop pancreatitis at a higher rate than the general population..$^{20,64}$

\section{Conclusion}

These preliminary data on incretins vs SGLT2-I show that patients treated with incretins and SGLT2-I did not have reduced cognitive performance during the 12 months of treatment. Metabolic outcome seemed to benefit in both treatments. Our study is still limited by a relatively small sample size. In addition, only a 12-month follow-up has been assessed and we considered this to be exploratory work.

Further studies are needed to evaluate the expected neuroprotective effects of these 2 classes of drugs since our study only included 50 patients and lasted only 12 months.

\section{Acknowledgments}

All procedures performed in studies involving human participants were in accordance with the ethical standards of the institutional research committee of University of Pavia and with the 1964 Helsinki declaration and its later amendments or comparable ethical standards.

\section{Disclosure}

The authors report no conflicts of interest in this work.

\section{References}

1. Kodl CT, Seaquist ER. Cognitive dysfunction and diabetes mellitus. Endocr Rev. 2008;29(4):494-511.

2. Saedi E, Gheini MR, Faiz F, Arami MA. Diabetes mellitus and cognitive impairments. World J Diabetes. 2016;7(17):412-422.

3. Ott A, Stolk RP, van Harskamp F, Pols HA, Hofman A, Breteler MM Diabetes mellitus and the risk of dementia: The Rotterdam Study. Neurology. 1999;53(9):1937-1942.

4. Leibson CL, Rocca WA, Hanson VA, et al. Risk of dementia among persons with diabetes mellitus: a population-based cohort study. Am J Epidemiol. 1997;145(4):301-308.

5. Ojo O, Brooke J. Evaluating the Association between Diabetes, Cognitive Decline and Dementia. Int $J$ Environ Res Public Health. 2015;12(7):8281-8294.

6. Zilliox LA, Chadrasekaran K, Kwan JY, Russell JW. Diabetes and Cognitive Impairment. Curr Diab Rep. 2016;16(9):87.

7. Cukierman T, Gerstein HC, Williamson JD. Cognitive decline and dementia in diabetes - systematic overview of prospective observational studies. Diabetologia. 2005;48(12):2460-2469.

8. Nandipati S, Luo X, Schimming C, Grossman HT, Sano M. Cognition in non-demented diabetic older adults. Curr Aging Sci. 2012;5(2):131-135.

9. Cukierman-Yaffe T, Gerstein HC, Williamson JD, et al. Action to Control Cardiovascular Risk in Diabetes-Memory in Diabetes (ACCORD-MIND) Investigators). Relationship Between Baseline Glycemic Control and Cognitive Function in Individuals With Type 2 Diabetes and Other Cardiovascular Risk Factors. The Action to Control Cardiovascular Risk in Diabetes-Memory in Diabetes (ACCORDMIND) trial. Diabetes Care. 2009;32(2):221-226.

10. Meneilly GS, Cheung E, Tessier D, Yakura C, Tuokko H. The effect of improved glycemic control on cognitive functions in the elderly patient with diabetes. J Gerontol. 1993;48(4):M117-M121.

11. Whitmer RA. Type 2 diabetes and risk of cognitive impairment and dementia. Curr Neurol Neurosci Rep. 2007;7(5):373-380.

12. Umegaki H. Type 2 diabetes as a risk factor for cognitive impairment: current insights. Clin Interv Aging. 2014;9:1011-1019.

13. Strachan MW, Reynolds RM, Marioni RE, Price JF. Cognitive function, dementia and type 2 diabetes mellitus in the elderly. Nat Rev Endocrinol. 2011;7(2):108-114.

14. Holst JJ, Vilsbøll T, Deacon CF. The incretin system and its role in type 2 diabetes mellitus. Mol Cell Endocrinol. 2009;297(1-2):127-136.

15. Holst JJ, Gromada J. Role of incretin hormones in the regulation of insulin secretion in diabetic and nondiabetic humans. Am J Physiol Endocrinol Metab. 2004;287(2):E199-206.

16. Drucker DJ. The biology of incretin hormones. Cell Metab. 2006;3(3):153-165.

17. Deacon CF, Mannucci E, Ahrén B. Glycaemic efficacy of glucagon-like peptide-1 receptor agonists and dipeptidyl peptidase-4 inhibitors as add-on therapy to metformin in subjects with type 2 diabetes-a review and meta analysis. Diabetes Obes Metab. 2012;14(8):762-767.

18. Abd El Aziz MS, Kahle M, Meier JJ, Nauck MA. A meta-analysis comparing clinical effects of short- or long-acting GLP-1 receptor agonists versus insulin treatment from head-to-head studies in type 2 diabetic patients. Diabetes Obes Metab. 2017;19(2):216-227.

19. Rondanelli M, Perna S, Astrone P, Grugnetti A, Solerte SB, Guido D. Twenty-four-week effects of liraglutide on body composition, adherence to appetite, and lipid profile in overweight and obese patients with type 2 diabetes mellitus. Patient Prefer Adherence. 2016;10:407-413.

20. Koliaki C, Doupis J. Incretin-based therapy: a powerful and promising weapon in the treatment of type 2 diabetes mellitus. Diabetes Ther. 2011;2(2):101-121.

21. Rizzo MR, Barbieri M, Boccardi V, Angellotti E, Marfella R, Paolisso G. Dipeptidyl peptidase-4 inhibitors have protective effect on cognitive impairment in aged diabetic patients with mild cognitive impairment. J Gerontol A Biol Sci Med Sci. 2014;69(9):1122-1131.

22. Isik AT, Soysal P, Yay A, Usarel C. The effects of sitagliptin, a DPP-4 inhibitor, on cognitive functions in elderly diabetic patients with or without Alzheimer's disease. Diabetes Res Clin Pract. 2017;123:192-198. 
23. Mossello E, Ballini E, Boncinelli M, et al. Glucagon-like peptide-1, diabetes, and cognitive decline: possible pathophysiological links and therapeutic opportunities. Exp Diabetes Res. 2011;2011:281674.

24. Hamilton A, Patterson S, Porter D, Gault VA, Holscher C. Novel GLP-1 mimetics developed to treat type 2 diabetes promote progenitor cell proliferation in the brain. $J$ Neurosci Res. 2011;89(4):481-489.

25. Porter DW, Kerr BD, Flatt PR, Holscher C, Gault VA. Four weeks administration of Liraglutide improves memory and learning as well as glycaemic control in mice with high fat dietary-induced obesity and insulin resistance. Diabetes Obes Metab. 2010;12(10):891-899.

26. Kalra S. Sodium Glucose Co-Transporter-2 (SGLT2) Inhibitors: A Review of Their Basic and Clinical Pharmacology. Diabetes Ther. 2014;5(2):355-366.

27. Abdul-Ghani MA, Defronzo RA. Lowering plasma glucose concentration by inhibiting renal sodium-glucose cotransport. J Intern Med. 2014;276(4):352-363.

28. Nair S, Wilding JP. Sodium glucose cotransporter 2 inhibitors as a new treatment for diabetes mellitus. J Clin Endocrinol Metab. 2010;95(1):34 42.

29. Zaccardi F, Webb DR, Htike ZZ, Youssef D, Khunti K, Davies MJ. Efficacy and safety of sodium-glucose co-transporter-2 inhibitors in type 2 diabetes mellitus: systematic review and network meta-analysis. Diabetes Obes Metab. 2016;18(8):783-794.

30. Ferrannini E, Solini A. SGLT2 inhibition in diabetes mellitus: rationale and clinical prospects. Nat Rev Endocrinol. 2012;8(8):495-502.

31. Scheen AJ. Pharmacodynamics, efficacy and safety of sodium-glucose co-transporter type 2 (SGLT2) inhibitors for the treatment of type 2 diabetes mellitus. Drugs. 2015;75(1):33-59.

32. Zinman B, Wanner C, Lachin JM, et al. Empagliflozin, Cardiovascular Outcomes, and Mortality in Type 2 Diabetes. $N$ Engl $J$ Med. 2015;373(22):2117-2128.

33. Lin B, Koibuchi N, Hasegawa Y, et al. Glycemic control with empagliflozin, a novel selective SGLT2 inhibitor, ameliorates cardiovascular injury and cognitive dysfunction in obese and type 2 diabetic mice. Cardiovasc Diabetol. 2014;13:148.

34. American Psychiatric Association. Diagnostic and statistical manual of mental disorders (DSM-5 ${ }^{\circledR}$. 5th: American Psychiatric Pub; 2013.

35. Folstein MF, Folstein SE, Mchugh PR. "Mini-mental state". A practical method for grading the cognitive state of patients for the clinician. $J$ Psychiatr Res. 1975;12(3):189-198.

36. Grigoletto F, Zappalà G, Anderson DW, Lebowitz BD. Norms for the Mini-Mental State Examination in a healthy population. Neurology. 1999;53(2):315-320.

37. Frisancho AR. New standards of weight and body composition by frame size and height for assessment of nutritional status of adults and the elderly. Am J Clin Nutr. 1984;40(4):808-819.

38. Spinnler H, Tognoni G. Standardizzazione e taratura italiana di test neuropsicologici [Standardization and Italian setting of mental test]. Ital J Neurol Sci. 1987 (Suppl 8):21-120. Italian.

39. Abbate C, Luzzatti C, Vergani C. Matrix test: speed and accuracy of visual search in aging. G Gerontol. 2007;55:11-20.

40. Novelli G, Papagno C, Capitani E, Laiacona N, Vallar G, Cappa SF. Tre test clinici di ricerca e produzione lessicale [three clinical test in scientific production]. Taratura su soggetti normali. Archivio di Psicologia, Neurologia e Psichiatria. 1986;47(4):477-506. Italian.

41. Horner MD, Teichner G, Kortte KB, Harvey RT. Construct validity of the Babcock Story Recall Test. Appl Neuropsychol. 2002;9(2):114-116.

42. Rizvi SM, Shakil S, Biswas D, et al. Invokana (Canagliflozin) as a dual inhibitor of acetylcholinesterase and sodium glucose co-transporter 2: advancement in Alzheimer's disease- diabetes type 2 linkage via an enzoinformatics study. CNS Neurol Disord Drug Targets. 2014;13(3):447-451.

43. Arafa NM, Marie MA, Alazimi SA. Effect of canagliflozin and metformin on cortical neurotransmitters in a diabetic rat model. Chem Biol Interact. 2016;258:79-88.

44. Shaikh S, Rizvi SM, Shakil S, Riyaz S, Biswas D, Jahan R. Forxiga (dapagliflozin): Plausible role in the treatment of diabetes-associated neurological disorders. Biotechnol Appl Biochem. 2016;63(1):145-150.
45. Chen S, Sun J, Zhao G, et al. Liraglutide Improves Water Maze Learning and Memory Performance While Reduces Hyperphosphorylation of Tau and Neurofilaments in APP/PS1/Tau Triple Transgenic Mice. Neurochem Res. 2017;42(8):2326-2335.

46. Palleria C, Leo A, Andreozzi F, et al. Liraglutide prevents cognitive decline in a rat model of streptozotocin-induced diabetes independently from its peripheral metabolic effects. Behav Brain Res. 2017;321:157-169.

47. Kamble M, Gupta R, Rehan HS, Gupta LK. Neurobehavioral effects of liraglutide and sitagliptin in experimental models. Eur J Pharmacol. 2016;774:64-70.

48. Kosaraju J, Murthy V, Khatwal RB, et al. Vildagliptin: an antidiabetes agent ameliorates cognitive deficits and pathology observed in streptozotocin-induced Alzheimer's disease. J Pharm Pharmacol. 2013;65(12):1773-1784.

49. El Batsh MM, El Batch MM, Shafik NM, Younos IH. Favorable effects of vildagliptin on metabolic and cognitive dysfunctions in streptozotocininduced diabetic rats. Eur J Pharmacol. 2015;769:297-305.

50. Pintana H, Apaijai N, Chattipakorn N, Chattipakorn SC. DPP-4 inhibitors improve cognition and brain mitochondrial function of insulinresistant rats. J Endocrinol. 2013;218(1):1-11.

51. Tsai TH, Sun CK, Su CH, Ch S, et al. Sitagliptin attenuated brain damage and cognitive impairment in mice with chronic cerebral hypo-perfusion through suppressing oxidative stress and inflammatory reaction. $J$ Hypertens. 2015;33(5):1001-1013.

52. Gault VA, Lennox R, Flatt PR, Sitagliptin FPR. Sitagliptin, a dipeptidyl peptidase-4 inhibitor, improves recognition memory, oxidative stress and hippocampal neurogenesis and upregulates key genes involved in cognitive decline. Diabetes Obes Metab. 2015;17(4):403-413.

53. Tasci I, Naharci MI, Bozoglu E, et al. Cognitive and functional influences of vildagliptin, a DPP-4 inhibitor, added to ongoing metformin therapy in elderly with type 2 diabetes. Endocr Metab Immune Disord Drug Targets. 2013;13(3):256-263.

54. During MJ, Cao L, Zuzga DS, et al. Glucagon-like peptide-1 receptor is involved in learning and neuroprotection. Nat Med. 2003;9(9):1173-1179.

55. Mcclean PL, Gault VA, Harriott P, Hölscher C. Glucagon-like peptide-1 analogues enhance synaptic plasticity in the brain: a link between diabetes and Alzheimer's disease. Eur J Pharmacol. 2010;630(1-3):158-162.

56. Monami M, Dicembrini I, Mannucci E. Effects of SGLT-2 inhibitors on mortality and cardiovascular events: a comprehensive meta-analysis of randomized controlled trials. Acta Diabetol. 2017;54(1):19-36.

57. Chao EC, Henry RR. SGLT2 inhibition--a novel strategy for diabetes treatment. Nat Rev Drug Discov. 2010;9(7):551-559.

58. Sehgal V, Bajwa SJ, Sehgal R, Consalvo JA. Management of diabetes in the elderly with canagliflozin: A newer hypoglycemic drug on the horizon. J Pharmacol Pharmacother. 2014;5(4):227-231.

59. List JF, Woo V, Morales E, Tang W, Fiedorek FT. Sodium-glucose cotransport inhibition with dapagliflozin in type 2 diabetes. Diabetes Care. 2009;32(4):650-657.

60. Madsbad S. Review of head-to-head comparisons of glucagon-like peptide-1 receptor agonists. Diabetes Obes Metab. 2016;18(4):317-332.

61. Shyangdan DS, Royle P, Clar C, Sharma P, Waugh N, Snaith A. Glucagon-like peptide analogues for type 2 diabetes mellitus. Cochrane Database Syst Rev. 2011;(10):CD006423.

62. Dungan KM, Povedano ST, Forst T, et al. Once-weekly dulaglutide versus once-daily liraglutide in metformin-treated patients with type 2 diabetes (AWARD-6): a randomised, open-label, phase 3, non-inferiority trial. Lancet. 2014;384(9951):1349-1357.

63. Nauck MA, Friedrich N. Do GLP-1-based therapies increase cancer risk? Diabetes Care. 2013;36(Suppl 2):S245-252.

64. Dore DD, Seeger JD, Arnold Chan K. Use of a claims-based active drug safety surveillance system to assess the risk of acute pancreatitis with exenatide or sitagliptin compared to metformin or glyburide. Curr Med Res Opin. 2009;25(4):1019-1027. 
Clinical Pharmacology: Advances and Applications is an international, Visit http://www.dovepress.com/testimonials.php to read real quotes peer-reviewed, open access journal publishing original research, reports, from published authors.

reviews and commentaries on all areas of drug experience in humans.

The manuscript management system is completely online and includes

a very quick and fair peer-review system, which is all easy to use.

Submit your manuscript here: https://www.dovepress.com/clinical-pharmacology-advances-and-applications-journal 